\title{
JYRI MANNINEN
}

\section{AIKUISKASVATUKSEN MERKITYSTÄ ETSIMÄSSÄ}

\section{PERUSTELUT}

Miksi esitellä 1920-luvulla kirjoitettu kirja? Perusteluja on monia; ensinnäkin aikuiskasvatuksen didaktisten kysymysten kannalta Lindemanin kirjan merkitys on huomattava Deweyn progressiivisen kasvatuksen oppien soveltamisessa aikuiskasvatuksen alueella. Lindeman tuo selkeästi esiin pragmatismin periaatteet ja aikuiskasvatuksen merkityksen sosiaalisen muutoksen välineenä. Kun otetaan vielä huomioon, että Malcolm Knowlesin andragogisen lähestymistavan perusperiaatteet on suoraan poimittu Lindemanin teoksesta (kts. Knowles 1984, 28-31; Knowles 1985, 3 sekä Manninen \& al. 1988, 10), asettuu nyt arvioitu kirja hyvin keskeiseen asemaan nykypäivän aikuiskasvatuksessa.

Vaikkakin Lindemanin teos on parhaiten ymmärrettävissä historiallisen ja sosiaalisen syntykontekstinsa kautta, sillä on yllättävän paljon annettavaa myös tämän päivän suomalaiselle aikuiskasvatukselle. Maailmansotien välisenä yhteiskunnallisesti levottomana aikana kirjoitettu kirja ottaa kantaa silloin ajankohtaisiin asioihin tavalla, joka ei ole menettänyt merkitystään tänäkään päivänä. Lindeman sivuaa kirjassa mm. rauhankasvatusta, ammattiyhdistysliikettä, demokratiaa, valtaa ja yksilön ja yhteisön suhdetta koskevia teemoja tavalla, joka varmasti antaa ajattelemisen aihetta jokaiselle aikuisopiskelun kanssa tekemisissä olevalle vielä nykyäänkin.

Lindemanin teos The Meaning of Adult Education on siten itsessään historiallinen merkkite-
Eduard C. Lindeman 1926/1989. The Meaning of Adult Education. Oklahoma Research Center for Continuing Professional and Higher Education. 143 sivua.

os, mutta samalla se 'valaisee nykyisyyttä ja paljastaa tulevaa'(Kidd 1989, xxvi). Juuri ajankohtaisuuden vuoksi kirjan toinen uusintapainos (1989) ja tämä kirja-arviointi ovat perusteltavissa. 1926 julkaistu painos oli vuosikymmeniä loppuunmyyty, ja myös 1961 tuotettu toinen painos loppui hyvin nopeasti.

Viime vuosina kiinnostus Lindemanin teosta kohtaan on tiettävästi lisääntynyt USA:ssa uudelleen, kun on alettu etsiä amerikkalaisen aikuiskasvatuksen 'esiknowlesilaisia' juuria. Suomessa kirjaa ei tiettävästi ole kovin paljon ollut saatavilla, ja kirjastojen yhteisluettelon 2/90 perusteella teosta ei olisi missään kirjastossa. Helsingin yliopiston kasvatustieteen laitoksen kirjastoon se tilattuna ilmestyi joulukuussa 1991.

Tämä kirja-arviointi on siten perusteltavissa paitsi kirjan sisällöllisen ja historiallisen merkityksen kautta, myös eräänlaisena Suomen 'ensiesittelynä'. Teos on elävästi kirjoitettu, ajatuksia herättävä kannanotto aikuisopiskelua koskeviin kysymyksiin, ja vaikka teokseen onkin runsaasti viitattu eri yhteyksissä, sille ei ole ehkä osattu ainakaan Suomessa antaa asiaankuuluvaa arvoa.

\section{EDUARD LINDEMAN}

Tässä arvioinnissa jätän Lindemanin persoonan esittelyn vähemmälle, koska aiheesta on helposti löydettävissä kattavaa kirjallisuutta (Brookfield 1983, 1984; Steward 1987 sekä Longin ja Kiddin esipuheet itse kirjassa). Lyhyesti voidaan todeta, 
että Lindeman oli filosofi ja sosiaalityön professori, pitkän linjan itseoppinut aikuisopiskelija ja -kasvattaja. Merkittävimmän elämäntyönsä Lindeman teki työläisten ja sosiaalityön parissa, painottaen aina aikuiskasvatuksen merkitystä demokraattisen yhteiskunnan luomisessa. Suurimmat vaikutteensa Lindeman sai Deweyn pragmatismista sekä Euroopasta, erityisesti Englannin ja Tanskan kansansivistystyöstä, jonkin verran myös Saksasta.

Lindeman oli koulutusoptimisti ja idealisti, mutta samalla hyvin käytännöllinen ja persoonallinen aikuiskasvattaja. Lindemanin mukaan muutosta ei synny ajattelemalla, toivomalla tai sattumalta - vain kovalla työllä ja opiskelun ja toiminnan yhdistämisellä voidaan saavuttaa todellisia muutoksia. Usko kasvatuksen yhteiskuntaa muuttavaan voimaan oli läpitunkeva, ja se on nähtävissä myös nyt arvioitavassa kirjassa.

\section{YLEISKUVA}

The Meaning of Adult Education ja siinä esitetyt ajatukset on helppo kuvata termeillä pragmatismi, humanismi, kasvatusoptimismi ja demokratia. Kirjan kantava teema on yleissivistävän aikuiskasvatuksen merkityksen korostaminen ja aikuisten sekä nuorten kapea-alaisen kouluttamisen kritisointi. Lindeman kritisoi kouluoppimisen perinteistä sosiaalistamistehtävää ja aikuisten ajattelumallien siirtämistä jälkipolville. Näkemys oppimisesta 'prosessina, joka päättyy kun oikea elämä alkaa' saa jyrkän tuomion.

Kirja on jaettu kymmeneen erilliseen lukuun, joissa Lindeman ottaa kantaa opiskeluun, älykkyyteen, niiden mukanaan tuomaan valtaan, itsensä toteuttamiseen, luovuuteen sekä vapauteen. Kapea-alaisesti erikoistuneet asiantuntijat saavat kuulla kunniansa, samoin sivistystä ali-arvioiva ammattiyhdistysliike ja ammattikorkeakoulut. Lopuksi Lindeman painottaa kollektiivisen kokemuksen merkitystä ja ottaa kantaa opiskelumenetelmiin.

Kirja on sujuvasti kirjoitettua filosofispainotteisesti kantaaottavaa tekstiä, joka paikoitellen tuntuu eksyvän asiasta, mutta jokainen tekstisivu löytää kuitenkin lopulta perustelunsa luvun lopussa. Kirjan paras anti löytyy ehkä syvällisistä mietteistä, joita löytyy paikoitellen:
'Thinking furnishes no energy for acting but merely uses left-over energies for purposes of justifying actions'. (s. 13).

'Habits belong to existence, intelligence to living'. (s. 17).

Kirjasta on löydettävissä orastavina - usein jopa kukoistavina - Knowlesin myöhemmin lainaamat kokemusperäisen oppimisen periaatteet, Mezirowin kriittisen tiedostamisen ja sosiaalisen muutoksen periaatteet sekä toiminnan teorian vaatimukset yhteisöllisestä oppimisesta.

Mielenkiintoista on myös Lindemanin aikalaisen Myles Hortonin ajatusten samankaltaisuus. Samoin kuin kognitiivisen didaktiikan periaatteet ovat löydettävistä jo Comeniuksen teksteistä, tuntuvat monet tänä päivänä uusina trendeinä elävät lähestymistavat löytyvän Lindemanin teoksesta. Monet niistä ovat nousseet pintaan eräänlaisina kollektiivisina totuuksina, toiset on tietoisesti tai tiedostamattomasti varastettu ja myyty uudelleen.

\section{AIKUISKASVATUKSEN MERKITYS JA MENETELMÄT}

Lindeman hyväksyy ammatillisen koulutuksen, jos se auttaa työn tekijää tiedostamaan työnsä merkityksen, mutta täsmällisemmin määriteltynä aikuiskasvatus alkaa siitä, missä ammatillinen koulutus loppuu. Aikuiskasvatuksen tarkoitus on luoda merkitys elämiselle. Aikuiskasvatuksen tulisi kohota 'leipä ja voi-linjalta' (s. 64) yksilön kehittymiseen ja elämisen mielekkyyden lisäämiseen. Lindeman on siten samoilla linjoilla antiikin kreikkalaisten kanssa, jotka hylkäsivät orjille suunnatut ammattiin tähtäävät artes serviles -tyyppiset opinnot vapaille kansalaisille sopimattomina.

Perinteinen kasvatus valmistaa yksilöä elämiseen, aikuiskasvatus on taas väline elämisen kehittämiseen. Aikuiskasvatuksen merkitys ei pysähdy yksilön kehittymiseen. Lindemanin näkemyksen mukaan yksilön kehityksen kautta saadaan aikaan yhteisön kehittyminen, jos lyhyentähtäimen tavoitteeksi asetetun yksilönkehityksen pohjalta päästään sitä toteuttamaan. Tähän päästään Lindemanin mukaan kehittämällä kollektiiviseen oppimiseen perustuvia oppimismenetelmiä.

Lindeman esittää perustelut elinikäisen oppimisen periaatteelle. Oppiminen kohdistuu tilanteisiin ja kokemuksiin, ei oppiaineisiin. Lähtö- 
kohtana ovat oppijan tarpeet ja kiinnostuksen kohteet, jotka syntyvät arkielämässä (työssä, kotona, yhteiskunnassa) koetuissa tilanteissa. Oppikirjat ja opettajat asettuvat uuteen rooliin, ja aikuisopettaja on myös itse oppija. Tärkein oppimistesurssi on oppijoiden oma kokemus - ei siis muiden kokemusten sijaiskokeminen kirjojen tai opetuksen kautta. Arkikokemuksen reflektointi ja merkitysten etsiminen on oppimisen lähtökohta:

\section{'Experience, the stuff out of which education is grown...' (s. 87) \\ 'Experience is, first of all, doing something; second, doing something that makes a diffe- rence; third, knowing what difference it ma- kes'. (s. 87) \\ 'Adult education is a process through which learners become aware of significant experien- ce'. (s. 109). \\ 'Education is the process and experience is the means for achieving evolutionary intelligence. The end is life transfused with meaning'. (s. 18).}

\section{Kuulostaa tutulta, eikö totta?}

Koulutuksen määrällinen lisääminen ei Lindemanin mukaan pysty perinteisen kasvatuksen ongelmia poistamaan, vaan on johtanut pelkästään koulutusprosessien mekanisoitumiseen ja formalisoitumiseen. Oppimisen valjastaminen yhteiskunnallisen muutoksen välineeksi vaatii sen sijaan uusia menetelmiä, motiiveja ja käsitteitä; ylipäätään koulutuksen laadullista kehittämistä.

\section{VALTA, VAPAUS JA ITSEOHJAUTUVUUS}

Lindeman esittää hyvin kilpailukykyisiä käsityksiä aikuisten itseohjautuvuudesta. Valta syntyy tiedostamisen kautta, mutta ei alistamalla toisia tai vapaus-käsitteen negatiivisen määrittelyn kautta; vapautena jostakin, kontrollin puutteena tai vapaana tahtona. Lindemanin mukaan erottamattomia yksiköitä (yksilö-yhteisö, kansalainenyhteiskunta) ei voi keinotekoisesti erottaa toisistaan, eikä vapautta jostakin (freedom from) ole tosiasiallisesti olemassa yksilön kohdalla ('only the insane complete the process'; s. 44). Ainoa mahdollinen vapaus on vapautta suhteessa johonkin (freedom-with).
Vapautumisen ensimmäinen edellytys on, että yksilö alkaa ymmärtää, mikä estää, turhauttaa tai alistaa häntä. (Samaa ideaahan on kehitelty eteenpäin Mezirowin, 1981, kriittisessä teoriassa; Lindemanin vaikutus/yhteys Frankfurtin koulukuntaan olisi mielenkiintoista selvittää, samoin kuin Lindemanin suora vaikutus Mezirowiin lähteenä Mezirowin ei Lindemania mainitse.) Opimme olemaan vapaita, kun tiedostamme miksi haluamme vapautta, ja mikä on oikeastaan halumme toteutumisen tiellä. Välineenä voi käyttää itsetuntemusta. Vapaus merkitsee omien kykyjen ja niiden rajallisuuden löytämistä, kokonaispersoonallisuuden hyödyntämistä (vrt. Platonin kasvatusideaali). Lindemanin mukaan vapaa yksilö toimii kuitenkin suhteessa ympäristöön ja muuttaa sitä aktiivisesti ja tietoisesti; vapaus riippuu älykkyydestä ja sitä voidaan kasvatuksella kehittää.

'Freedom can never be absolute. None of us is self-determined. Self is relative to other selves and to the inclusive environment. We live in freedom when we are conscious of a degree of self-direction proportionate to our capacities'. (s. 50).

Älykkyys, valta, itsensä toteuttaminen ja vapaus ovat merkityksellisiä vain, jos ne muodostavat toiminnallisen kokonaisuuden, kokonaispersoonallisuuden.

\section{ARVIOINTIA}

Lindemanin kirjassaan esittämät ajatukset ovat jääneet elämään paljolti Knowlesin andragogisina periaatteina (kts. Knowles 1985, 3), vaikka kirjalla ja Lindemanin ajatuksilla olisi varmasti ollut itseisarvoinenkin asema aikuiskasvatuksessa. Knowlesin andragogia on myös onnistunut osittain 'tappamaan' Lindemanilla esiintyneen kriittisen ja sosiaalisen tiedostamisen periaatteen, jonka Mezirow taas on nostanut uudelleen esille (kts. Manninen \& al. 1988, 6-7).

Tämän arvioinnin puitteissa on mahdotonta sanoa, oliko Lindeman vain ajassa liikkuvien ideoiden kirjaaja vai itsenäinen ajattelija, jonka tekstit ovat poikineet vuosien kuluessa lukuisia 'teorioita' ja lähestymistapoja (tosin alkuperäistä lähdettä tiedostamatta tai mainitsematta). Lindemanin teoksen itsenäinen merkitys on sen kyvyssä ottaa kantaa nykyäänkin ajankohtaisiin asioihin, kuten aikuisten itseohjautuvuuteen, elinikäiseen 
oppimiseen ja kriittiseen tiedostamiseen. Näistä aiheista kiinnostuneille kirja antanee uutta näkökulmaa ja pohdittavaa.

Itse tutustuin Lindemanin kirjaan alunperin Knowlesin (1984, 28-30) esittämien lainausten kautta sekä Brookfieldin $(1983,1984)$ artikkeleiden avulla. Kosketusetäisyydelle pääsin ensimmäistä kertaa 1989 Lontoon yliopiston kasvatustieteen laitoksen kirjastossa, mutta vasta toinen uusintapainos mahdollisti kirjan tilaamisen Suomeen. Kirjan ympärille muodostunut sädekehä ei kuitenkaan lukemisesta huolimatta haalistunut, vaan kirkastui entisestään; nerokas, syvällinen ja ajatuksia herättävä teos, jonka pitäisi kuulua jokaisen aikuiskasvattajan - ja miksei myös aikuiskouluttajan - lukemistoon. Vaikka teos voimakkaasti painottaa vapaan sivistystyön ja

\section{LÄHTEET}

Brookfield, S. 1983. Adult education and the democratic imperative: the vision of Eduard Lindeman as a contemporary charter for adult education. Studies in Adult Education. 15, 37-46.

Brookfield, S. 1984. The contribution of Eduard Lindeman to the development of theory and philosophy in adult education. Adult Education Quarterly 34, 4, 185-196.

Kidd, J. R. 1989/1961. Editor's preface to 1961 edition. In: E. Lindeman 1989. The Meaning of Adult Education. Oklahoma: Oklahoma Research Center for Continuing Professional and Higher Education.

Knowles, M.S. 1984. The adult learner: a neglected species. Houston: Gulf Publishing Company. englantilaistyyppisen aikuiskasvatuksen periaatteita, on sillä varmasti annettavaa myös 'raakaa' koulutustyötä tekeville. Sosiaalisen muutoksen, ammattiyhdistysliikkeen ja vallankäytön kysymyksistä kiinnostuneille kirja antaa varmasti uusia ajatuksia.

Lindemanin kirja soveltuu erinomaisesti esimerkiksi aikuiskasvatuksen syventävien opintojen kirjallisuudeksi; ei kuitenkaan tentittäväksi vaan luettavaksi.

'Wherever we have travelled we have heard favorable references to The Meaning of Adult Education, usually by those who have never seen it full. But it is a sorry fate for a fine book to be "referred to with respect". It ought to be read'. (Kidd 1989, xxxvi).
Knowles, M.S. (ed.) 1985. Andragogy in action. San Francisco: Jossey-Bass Publishers.

Lindeman, E. 1989. The Meaning of Adult Education. Oklahoma: Oklahoma Research Center for Continuing Professional and Higher Education.

Manninen, J. \& Kauppi, A. \& Kontiainen, S. 1988. Koulutussuunnittelun lähtökohtia. Analyysi Knowlesin andragogiasta didaktisena lähestymistapana. Helsingin yliopisto, kasvatustieteen laitos, tutkimuksia 116.

Mezirow, J. 1981. A Critical Theory of Adult Learning and Education. Adult Education 32, 1,3-24.

Stewart, D. 1987. Adult Learning in America: Eduard Lindeman and His Agenda for Lifelong Education. Malabar: Krieger Publishing co.
Eduard Lindeman's book 'The Meaning of Adult Education' is reprinted by Oklahoma Research Center for Cont. Professional and Higher Education, OCCE/200 McCarter Hall, Norman, Oklahoma 73037-0003, (405) $325-1080$, fax (405) $325-2620$. Price is $\$$ $14,95,143$ pages. 